\title{
WILDFIRE AND BALD EAGLES: SUMMER ON LAC LA RONGE SASKATCHEWAN IN 2015
}

Dale Mierau, C/O SMRC,

479 First Ave. N., Saskatoon, SK S7K 1X5 d.mierau@shaw.ca

For years I've observed breeding and non-breeding bald eagles (Haliaeetus leucocephalus) in a $70 \mathrm{~km}^{2}$ area on Lac La Ronge. Lac La Ronge is a large glacial lake situated on the southern border of the pre-Cambrian shield in northern Saskatchewan. A shoreline of $1,015 \mathrm{~km}$ surrounds a surface area of $1,413 \mathrm{~km}^{2}$ with 1,035 rocky islands.

Breeding bald eagles return to Lac La Ronge in late March and early April. During this critical time, stormy weather on the prairies can interfere with bald eagle migration with the end result of lower rates of reproduction Weather anomaly during bald eagle migration was identified as detrimental to reproduction at Besnard Lake in $1975,3,4$ Severe weather during the migration of breeding bald eagles in 2013 again resulted in low productivity at Besnard Lake ${ }^{2}$ and Lac La Ronge. ${ }^{5}$ In 2013, the area of observation on Lac La Ronge produced only one fledgling. In 2014, after a mild and early spring, bald eagle reproduction rebounded at Besnard Lake ${ }^{2}$ and the area of observation on Lac La Ronge, where eight young fledged. ${ }^{6}$

The spring of 2015 was mild on the prairies, without late snow storms.

In late May, eight nesting pairs were tending nests in the area of observation. A fuzzy, tawny-coloured head was visible at McCulloch Island on June 2 (Fig. 1).

A lightning storm on June 7, 2015 ignited wildfires that were to have serious consequences for Lac La Ronge bald eagles (Fig. 2). Dense smoke from wildfire filled the air on June 8, 2015 (Fig. 3).

The dense smoke resulted in poor visibility, interfered with breathing and irritated the eyes. Smoke-filled air would be the norm for the ensuing six weeks, until late July.

On June 20, a shift in the wind cleared the air enough for a day-trip to check on the nestlings. Two young occupied nests at McCulloch, Archer, Camp, and Jackson Islands (Fig. 4). The Howard and Town nests held one each.

As of June 20, 2015, there were ten nestlings in six nests.

I ventured on to the lake to check nests as often as weather and smoke allowed. The air cleared enough on June 27 for another extended tour to visit all the nests. On that day I found four nestling carcasses. The nestlings at Howard, Jackson had expired along with both young McCulloch (Fig. 5).

Fires continued to burn, with frequent flare-ups and an increasing density of smoke, even after the mandatory evacuation of the town and area on July 5 (Fig. 6).

The fire consumed forest and property in early July (Fig. 7)

Only two Bald Eagle young remained alive on July 6 - one at Archer and one at Jackson (Fig. 8)

Smoke from wildfires made lake travel a challenge. Excursions to nests were necessarily brief and limited to one or two per trip (Fig. 9)

The air cleared in late July with the onset of cooler weather and rain. The nestlings at Archer and Jackson had survived. Adults no longer attended the nests at Camp, Howard, McCulloch and Town.

The weather became warm and dry in late July. Wildfires, which resulted in more smoke and poor visibility, rekindled on the west, north, northeast, east and south east sides of the lake (Fig. 10).

During the first week in August, the immediate threat of smoke from wildfire came to an end. The fledgling at Archer appeared robust and on track for self-reliance. However, the fledgling at Jackson appeared less capable. She left the nest later than usual and did not (for some reason) sit at the nest for almost a week despite being close to it

She was very vocal and her calls could be heard for kilometres at all times of the day (Fig. 11).

She was still not self-reliant by midSeptember when she waited to be fed on a rock near a hunting perch (Fig. 12)

In the spring of 2015, there were signs of a productive season for Lac La Ronge bald eagles. However, a shroud of dense smoke from wildfires created poor visibility and interfered with the gathering of food for the young. Only two of the ten nestlings in the area of observation survived to fledge. Near the end of the season, it was my impression that only one of the two survivors was fit enough to survive the migration south

\section{Acknowledgements:}

The author would like to thank Robert MacPherson for his contribution of the images of the burning cabin and small island.

\section{References:}

1. https://en.wikipedia.org/wiki/Lac_la_Ronge

2. Gerrard JM, personal communication April 2016.

3. Gerrard JM, Bortolotti GR. (1988) The Bald Eagle. Haunts and Habits of a Wilderness Monarch. Smithsonian Institution Press. Washington and London. pp 77-78.

4. Gerrard, J.M., P.N. Gerrard, G.R. Bortolotti, and E.H.Dzus. (1992a.) A 24-year study of bald eagles on Besnard Lake, Saskatchewan. Journal of Raptor Research 26:159-166.

5. Mierau D. (2014) A disastrous year for Bald Eagles at Lac La Ronge Saskatchewan in 2013. Blue Jay 72:86-96

6. Mierau D. (2015) Observations of Bald Eagles on Lac La Ronge in 2014. Blue Jay $73 \cdot 69-84$ 


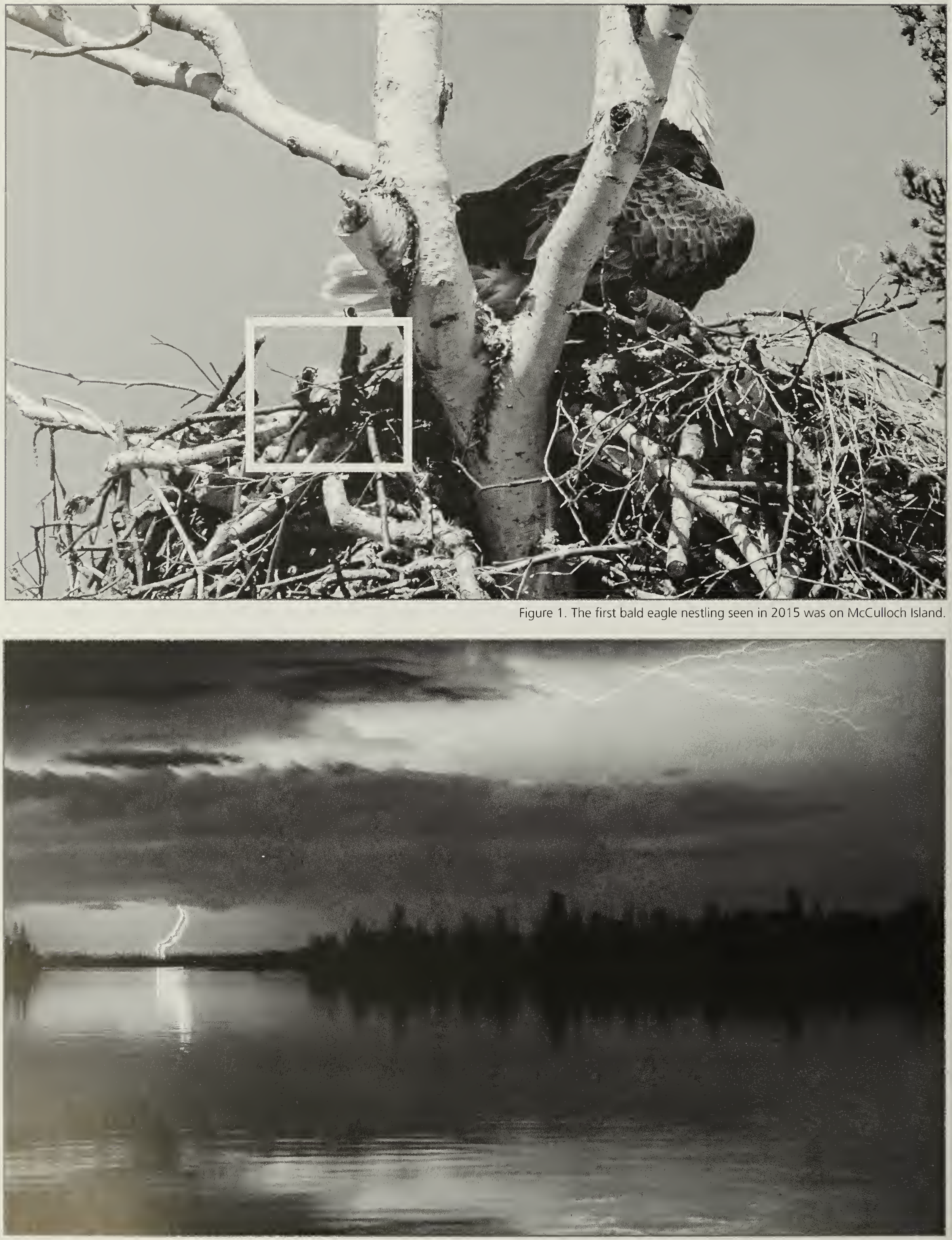

Figure 2. Lightning filled the sky over Lac La Ronge during the night of June 7, 2015. 


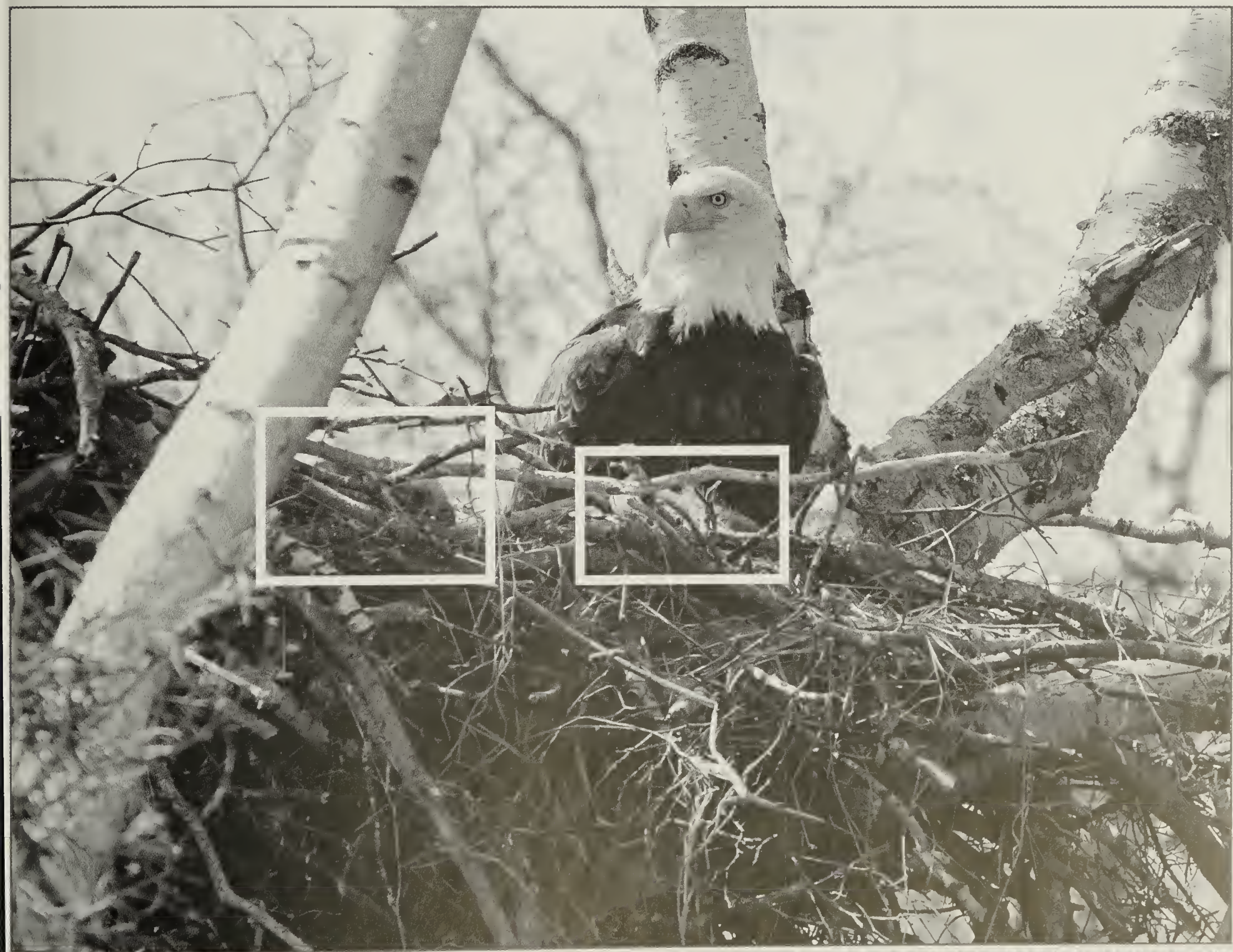

Figure 4. Two young were visible at Archer Istand on June 20 


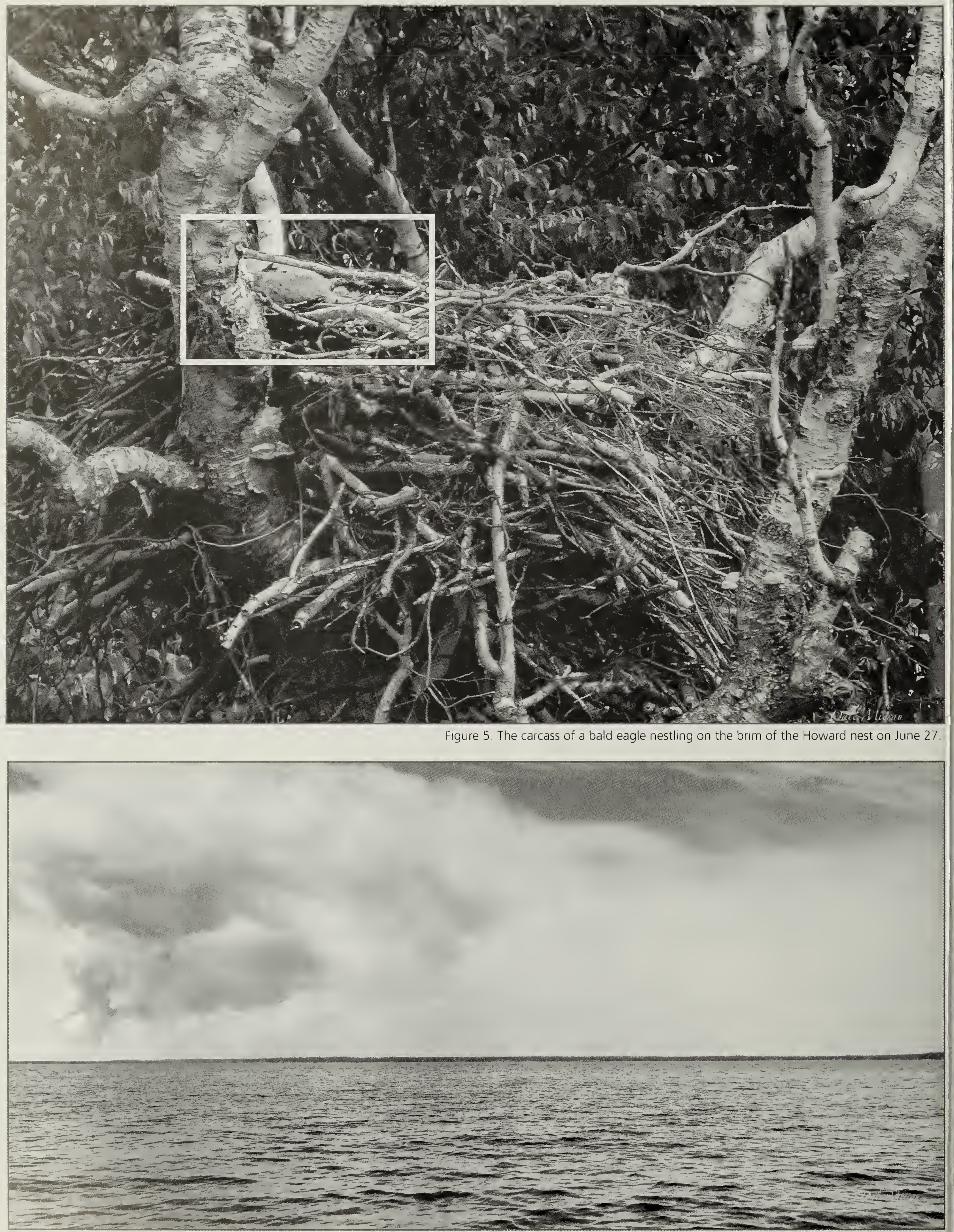




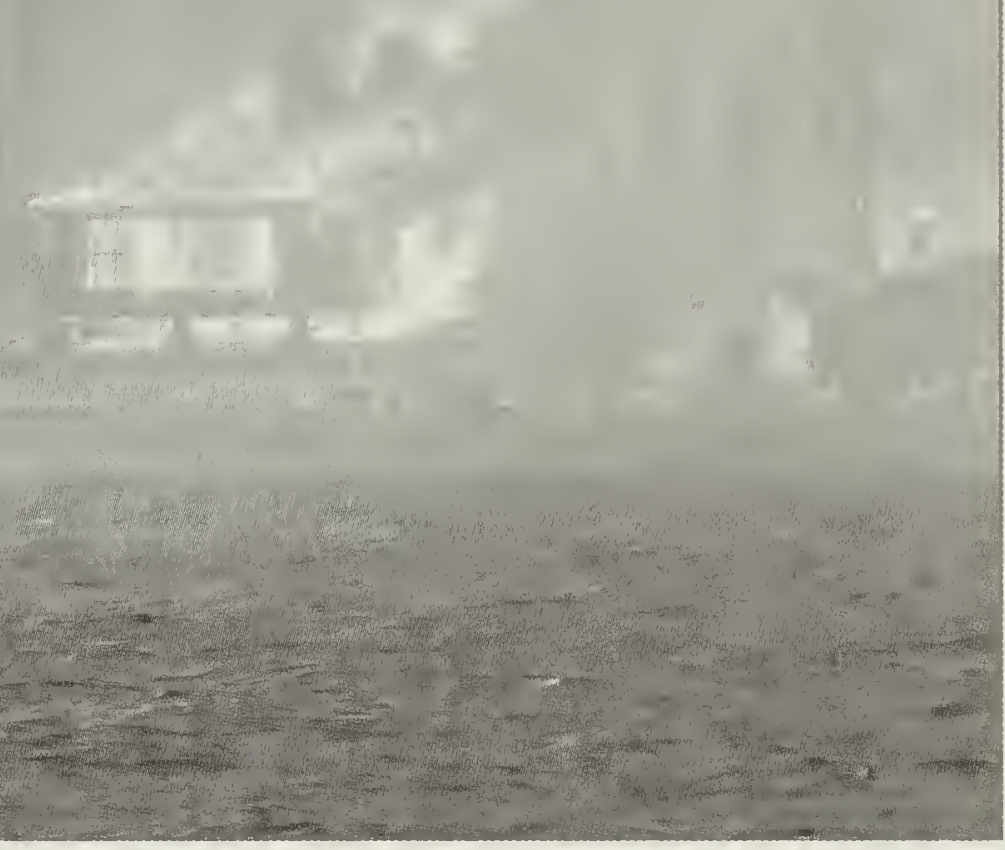

Figure 7. The shores of Lac La Ronge were ablaze on July 5, 2015

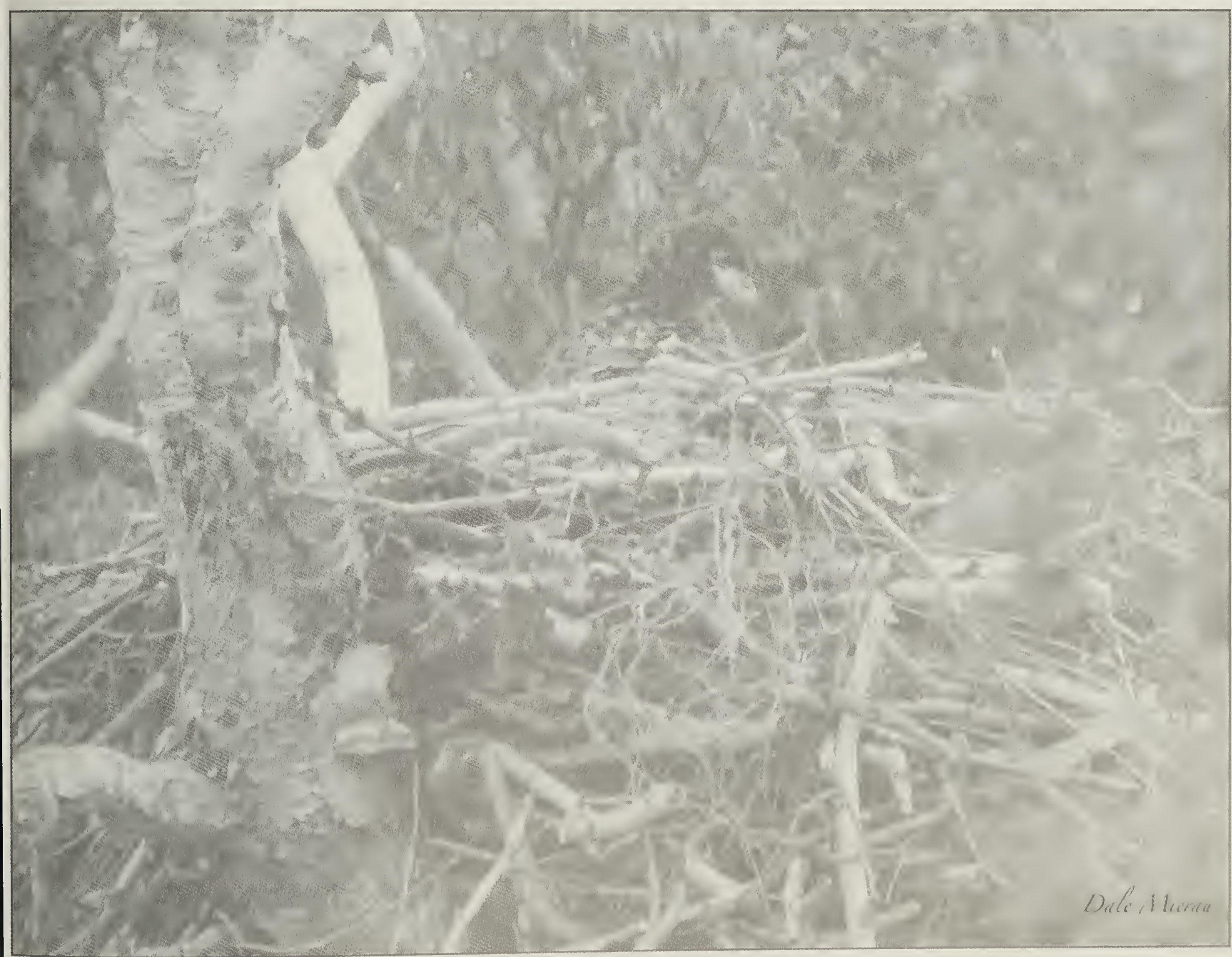

Figure 8. The surviving nestling at the Jackson nest, partially obscured by smoke on July 6 


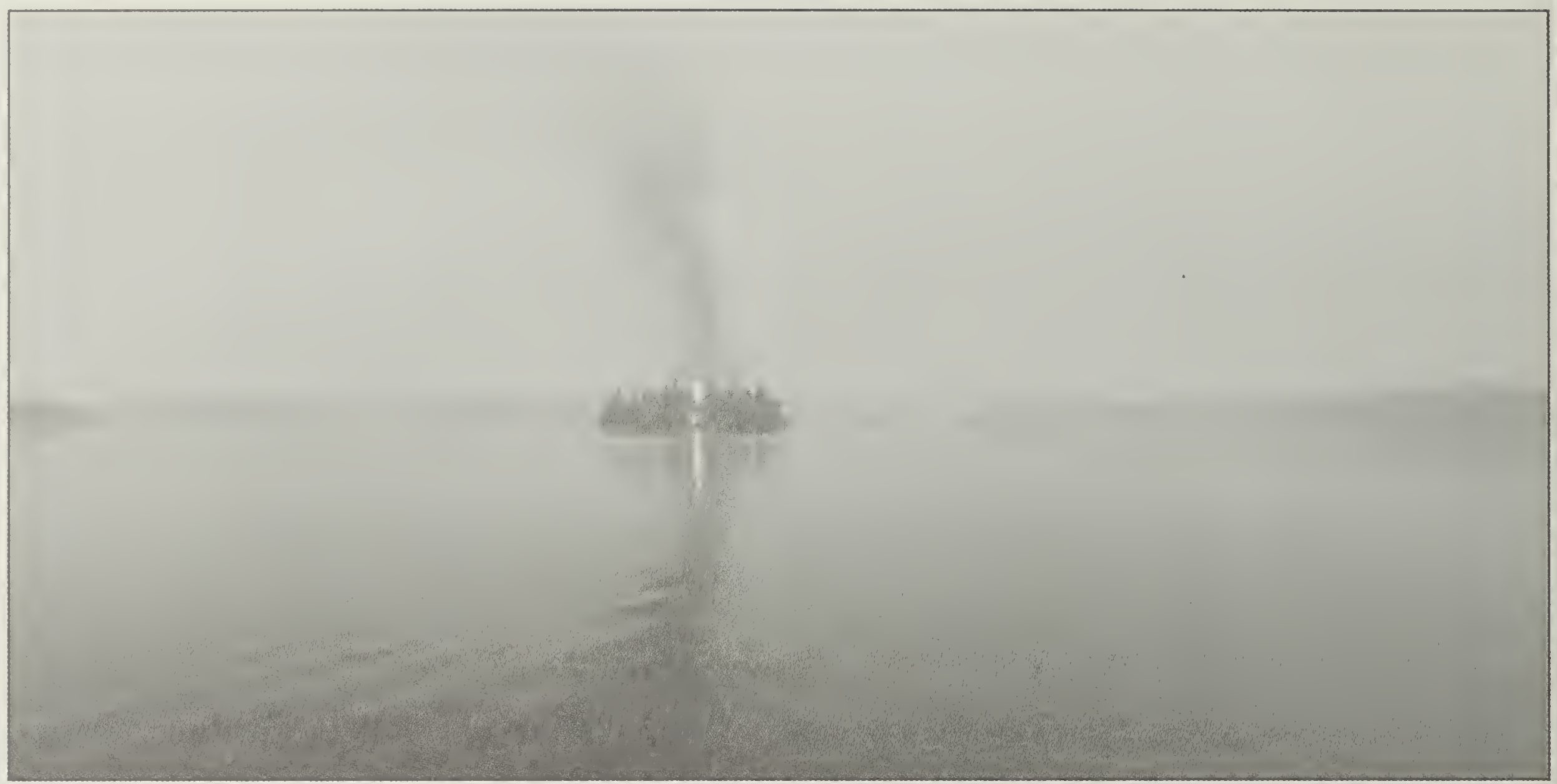

Figure 9. A small, isolated island was ablaze on July 8 , likely from an airborne burning leaf.

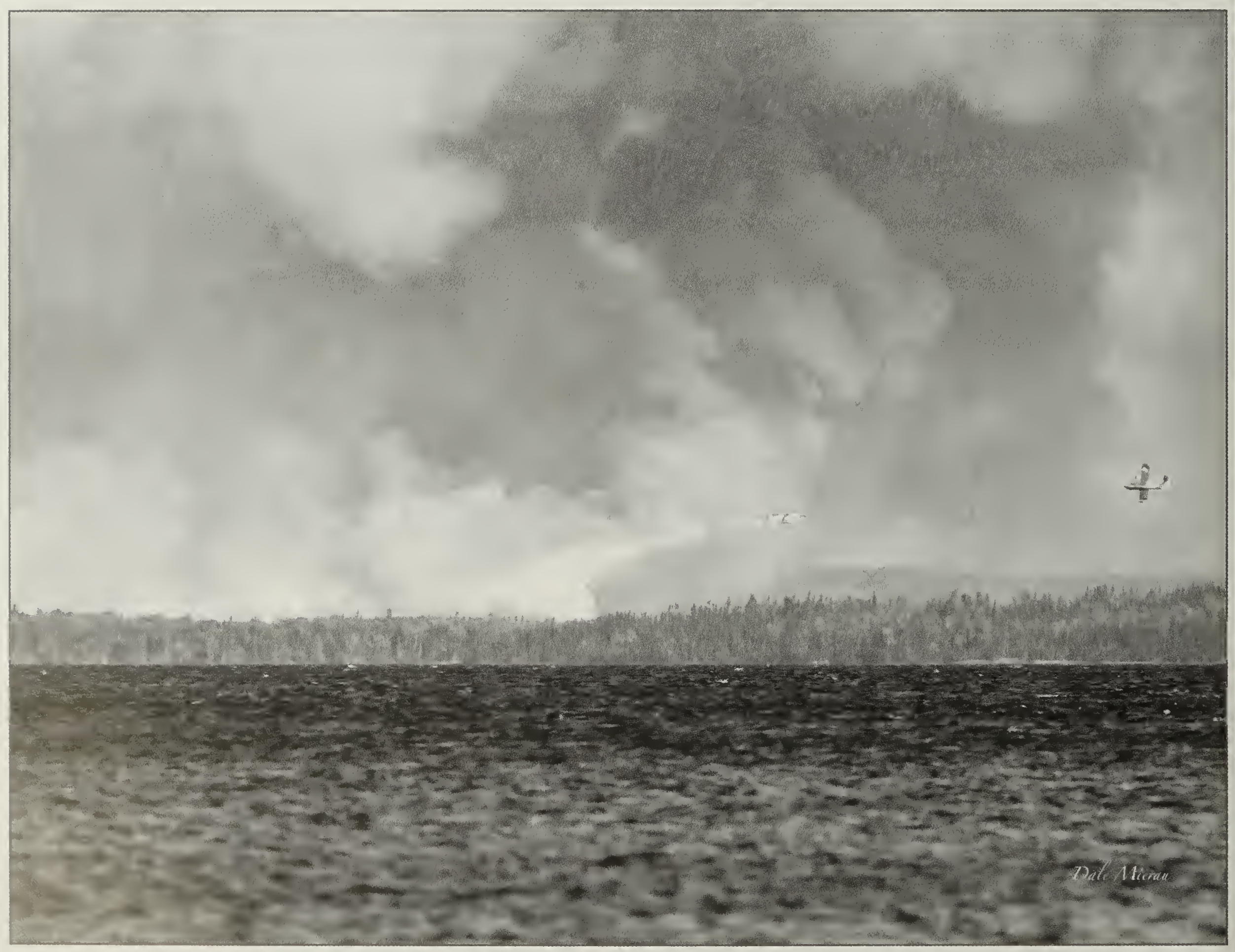

Figure 10. Firefighters responded with force to an aggressive fire flared up in the Hunter Bay area on August 2. 


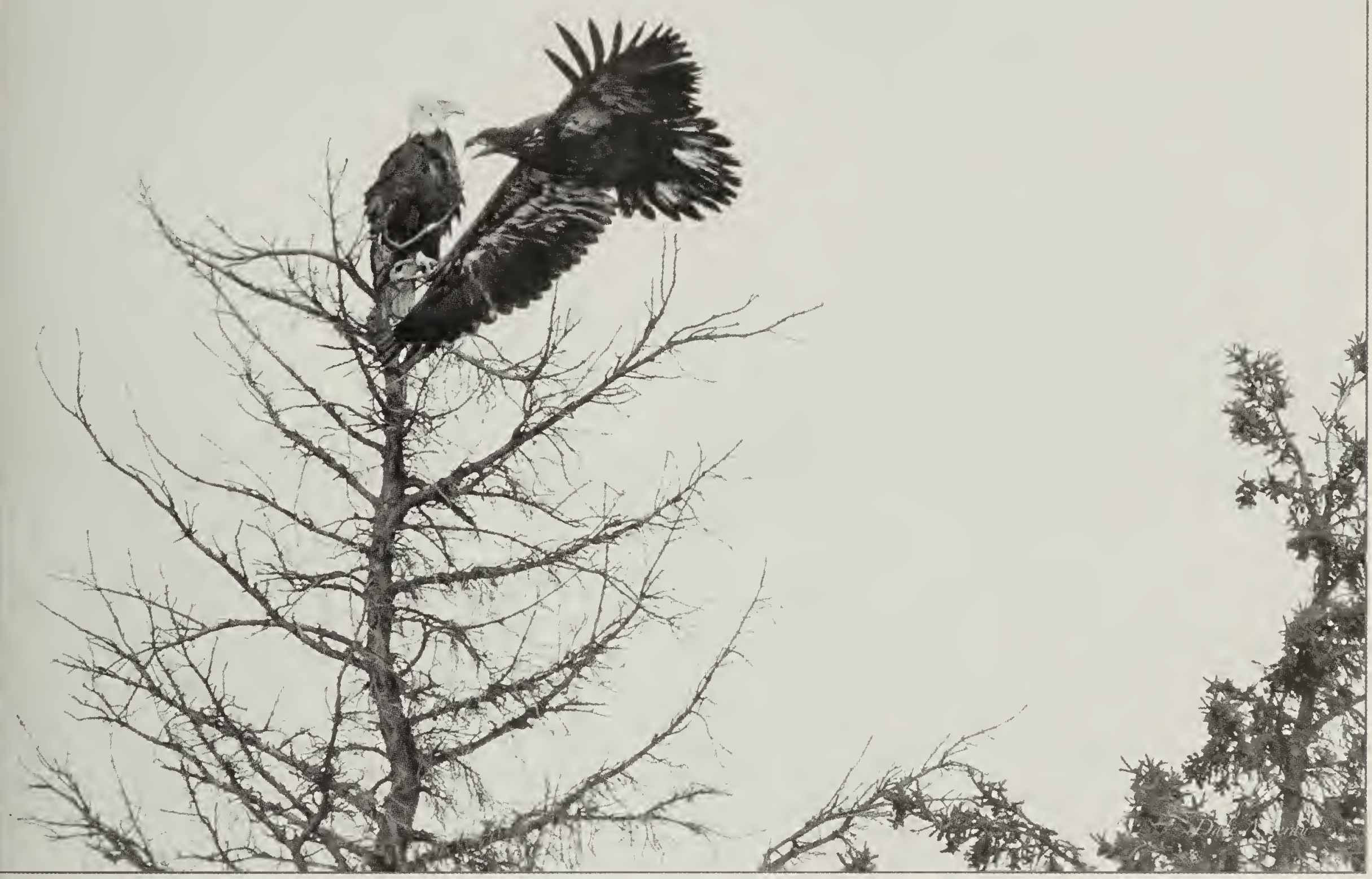

Figure 11. The fledgling at the Jackson nest continued to pester its parents well past the time that it should have been hunting successfully.

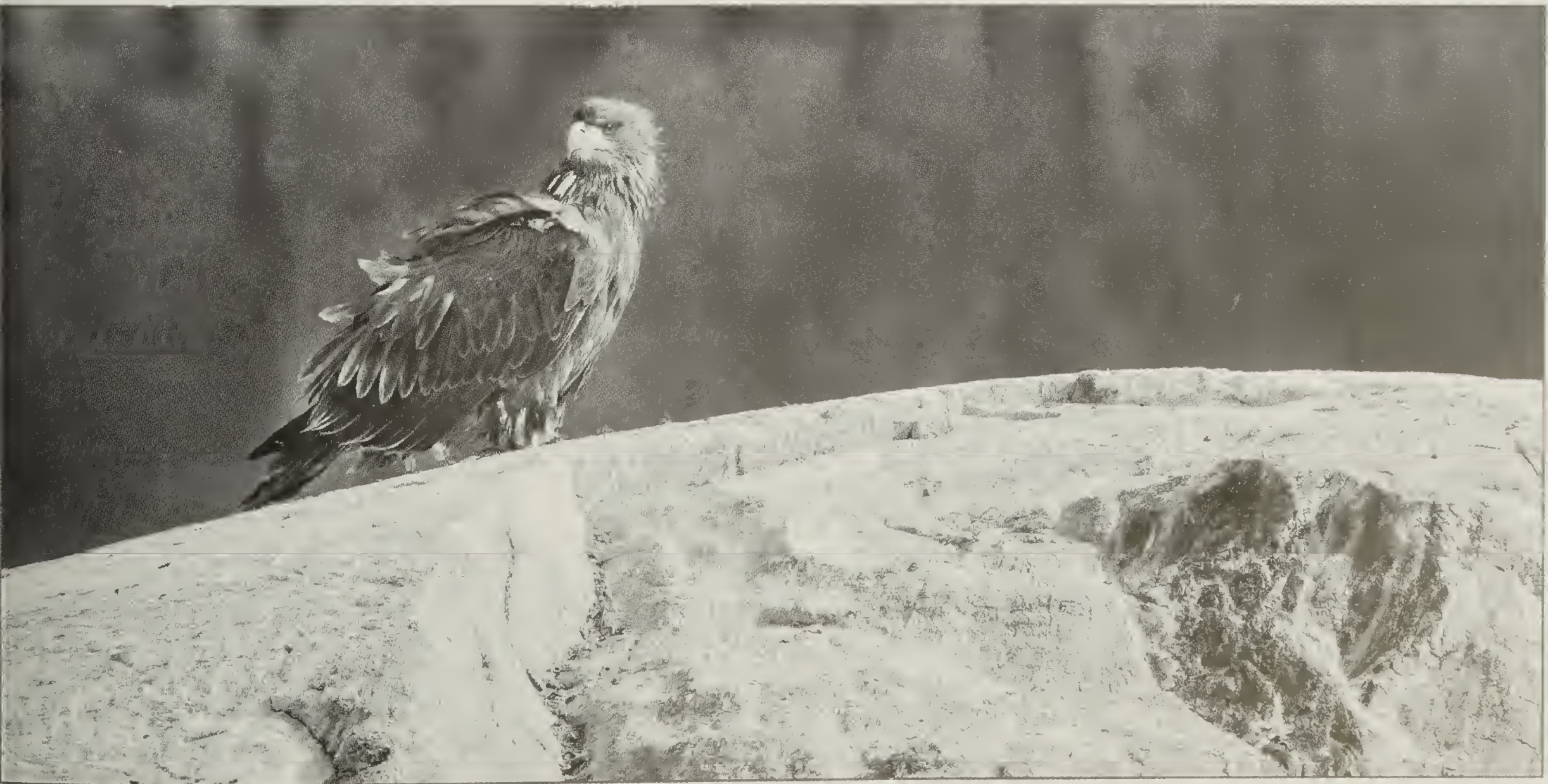

